\title{
Experimental Research on the Mechanical Properties of Steel Slag Recycled Aggregate Concrete
}

\author{
Yun Dong ${ }^{1,2}$, Hui Wang ${ }^{1}$ and Junjie Gong ${ }^{1}$ \\ ${ }^{1}$ Key Laboratory of Solid Waste Recycling and Utilization of Huai'an, Jiangsu, China, 223001 \\ ${ }^{2}$ Faculty of Civil Engineering and Architecture, Huaiyin Institute of Technology, Jiangsu, Huai'an, China, 223001
}

\begin{abstract}
This article is aimed to discover the effect of replacement rate of slag recycled aggregate on the compressive strength of recycled concrete. The slag has been crushed and sieved to regenerate recycled aggregate, than replaced the different ratio of natural aggregate with recycled aggregate in premixed recycled concrete, carried out compressive strength test. The test results show that partially replace the natural aggregate with recycled aggregate regenerated from steel slag in concrete is feasible, and it can improve the early age compressive strength of recycled concrete. The appropriate replacement ratio of natural aggregate is about $20 \%$ consider the long-term strength. The research results have been applied in recycled concrete which used in foundation engineering, and it has been proved that it can bring good economic and environmental benefits.
\end{abstract}

Keywords-steel slag; coarse aggregate; recycled concrete; compressive strength

\section{INTRODUCTION}

Steel slag is a kind of industrial tailings which produced in the process of steelmaking, its discharge is about $15 \%$ to $20 \%$ of the crude steel production. As a result of the fluctuations of the steel slag composition is changing unusually, the recycle of its high added value has been more difficult. But the producer research on efficient utilization of steel slag has not stopped, invested a lot of people, money and material resources to the development and application. European and American developed countries, the recycling of steel slag are relatively high, but is only limited to the iron and steel industry, are generally use various methods to recovery of these metals, and in related industries such as construction concrete of steel slag utilization is seldom involved ${ }^{[1]}$.Many domestic scholars have also committed to the efficient utilization of steel slag, and done some research in steel slag recycled materials and its application ${ }^{[2-6]}$, but because of the stability and durability of the steel slag concrete issues not been completely resolved, such as using steel slag recycled aggregate instead of natural aggregate in concrete of the research and application of recycled concrete has been stagnant. In order to promote the closure of the end of the steel slag recycled materials applied in concrete, this study from the study of the strength of the steel slag recycled aggregate concrete change rule, through different steel slag content of recycled aggregate replace the natural aggregate strength test of steel slag concrete, steel slag recycled aggregate content on the influence of steel slag recycled concrete strength are studied.

\section{II.EXPERIMENTAL OF THE RAW MATERIAL}

(1) The cement used in this experiment is composite Portland cement 42.5 R made in Huaian Conch Cement Co. Ltd. And the physical performance index are shown in table 1, chemical components are shown in table 2.

(2) The sand used in experimental is natural river sand, measured the silt content is $2.3 \%$, fineness modulus is 2.6 , which belong to medium sand. The aggregate used in this study are come from Huaian stone material factory, specific technical indicators as shown in table 3.

(3) The steel stags used in this study are come from Huaigang Special Steel Co. Ltd, the appearance of steel slag recycled aggregate after crushing and sieving are shown in figure 1.

TABLE I. INDEX OF CEMENT

\begin{tabular}{|c|c|c|c|c|c|c|c|c|}
\hline \multirow[b]{2}{*}{ Density（g/cm3） } & \multirow[b]{2}{*}{$\begin{array}{c}\text { Requirement of } \\
\text { normal consistency } \\
(\%)\end{array}$} & \multicolumn{2}{|c|}{ Time of setting } & \multirow[b]{2}{*}{$\begin{array}{l}\text { Age } \\
\text { (d) }\end{array}$} & \multicolumn{2}{|c|}{ Rupture strength } & \multicolumn{2}{|c|}{ Compression strength } \\
\hline & & $\begin{array}{l}\text { Initial setting } \\
\text { time }(\min )\end{array}$ & $\begin{array}{l}\text { Final setting } \\
\text { time }(\min )\end{array}$ & & $\begin{array}{l}\text { Measured value } \\
(\mathrm{MPa})\end{array}$ & $\begin{array}{c}\text { Standard set } \\
\text { value } \\
(\mathrm{MPa}) \\
\end{array}$ & $\begin{array}{l}\text { Measured value } \\
(\mathrm{MPa})\end{array}$ & $\begin{array}{c}\text { Standard set } \\
\text { value } \\
(\mathrm{MPa}) \\
\end{array}$ \\
\hline \multirow{2}{*}{3.1} & \multirow{2}{*}{27.9} & \multirow{2}{*}{196} & \multirow{2}{*}{247} & 3 & 5.1 & $\geq 3.5$ & 21.5 & $\geq 17.0$ \\
\hline & & & & 28 & 9.6 & $\geq 6.5$ & 45.9 & $\geq 42.5$ \\
\hline
\end{tabular}

TABLE II. CHeMICAL COMPOSITION OF CEMENT

\begin{tabular}{cccccccccccc}
\hline Chemical composition & $\mathrm{SiO} 2$ & $\mathrm{~A} 2 \mathrm{O} 3$ & $\mathrm{CaO}$ & $\mathrm{MgO}$ & $\mathrm{Na} 2 \mathrm{O}$ & $\mathrm{K} 2 \mathrm{O}$ & $\mathrm{Fe} 2 \mathrm{O} 3$ & $\mathrm{SO} 3$ & $\mathrm{Tio} 2$ & $\mathrm{MnO}$ & $\mathrm{P} 2 \mathrm{O} 5$ \\
\hline Content $(\%)$ & 20.73 & 3.72 & 63.11 & 1.62 & 0.48 & 0.73 & 3.15 & 0.86 & 0.16 & 0.06 & 0.05 \\
\hline
\end{tabular}


TABLE III. MAIN SPECIFICATIONS OF AGGREGATE

\begin{tabular}{|c|c|c|c|c|c|c|c|c|}
\hline Grain size & \multicolumn{2}{|c|}{ Dense packing density } & Close void ratio & Bulk density & Loose porosity & Crushing value & $\mathrm{Sec}$ & ent percentage \\
\hline \multicolumn{2}{|l|}{$5 \mathrm{~mm} \sim 31.5 \mathrm{~mm}$} & $1.58 \mathrm{~g} \cdot \mathrm{cm}-3$ & $42.3 \%$ & $1.5 \mathrm{~g} \cdot \mathrm{cm}-3$ & $45.3 \%$ & $8.1 \%$ & & $0.79 \%$ \\
\hline \multicolumn{9}{|c|}{ TABLE IV. PHYSICAL INDICATORS OF SLAG RECYCLED AGGREGATE } \\
\hline grain size & apparent density & Bulk density & Loose porosity & Dense packing & Close vo & water $a b$ & ion & crushing value \\
\hline $5 \sim 25 \mathrm{~mm}$ & $3392 \mathrm{~kg} / \mathrm{m} 3$ & 1984 kg/m3 & $41.5 \%$ & $2062 \mathrm{~kg} / \mathrm{r}$ & 39.2 & 4.5 & & $9.4 \%$ \\
\hline
\end{tabular}

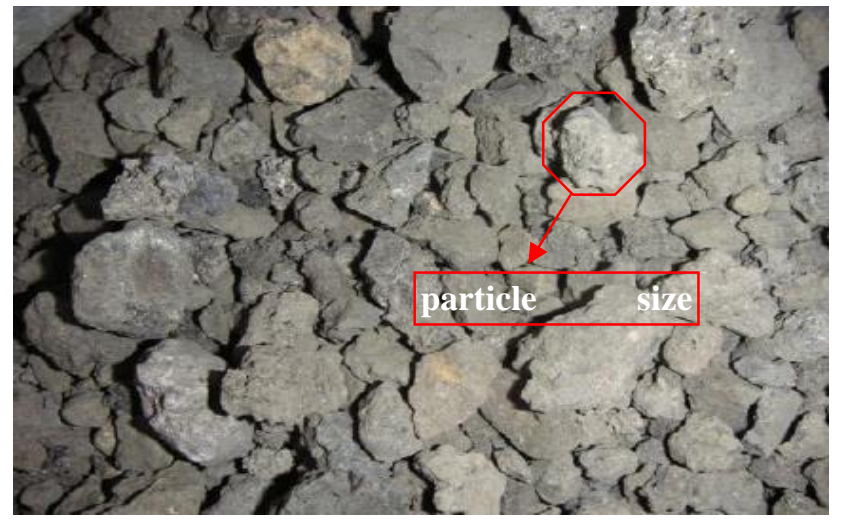

FIGURE I. STEEL SLAG RECYCLED AGGREGATE USED IN THIS ARTICLE

It can be seen that the surface of recycled aggregate is rough, and distributed many micro pore, the specific physical indicators of steel slag recycled aggregate are shown in table 4.

\section{MIX PROPORTIONS AND TEST RESULTS}

This experiment take the C30 strength grade, $60 \sim 90 \mathrm{~mm}$ slump, $0 \%$ of the steel slag replacement rate as control group, named as YUA-01, the experimental group was $20 \%, 40 \%$, $60 \%, 80 \%$ and $100 \%$ of natural aggregate replacement rate with steel slag recycled aggregate.
This test select $7 \mathrm{~d}$ and $28 \mathrm{~d}$ compressive strength to disclose the change trend of the five groups between different age and replacement ratio.

The mix proportions of steel slag concrete are shown in the table 5 .

The compressive strength of steel slag recycled concrete was shown in figure $2,7 \mathrm{~d}$ and $28 \mathrm{~d}$, respectively.

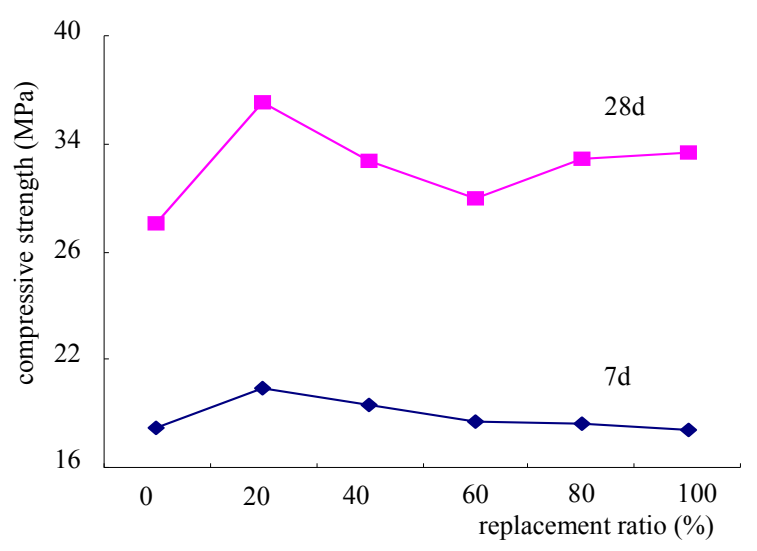

FIGURE II. TREND OF STEEL SLAG RECYCLED AGGREGATE CONCRETE'S COMPRESSIVE STRENGTH

TABLE V. MIX PROPORTIONS OF SLAG RECYCLED AGGREGATE CONCRETE

\begin{tabular}{|c|c|c|c|c|c|c|c|}
\hline \multirow{2}{*}{$\begin{array}{l}\text { Specimen } \\
\text { number }\end{array}$} & \multirow{2}{*}{$\begin{array}{l}\text { Water cement } \\
\text { ratio }\end{array}$} & \multirow{2}{*}{$\begin{array}{c}\text { Substitution rate of recycled } \\
\text { aggregate }(\%)\end{array}$} & \multicolumn{5}{|c|}{ Per cubic meter of slag recycled aggregate concrete material dosage $(\mathrm{m} 3 / \mathrm{kg})$} \\
\hline & & & Water & Cement & Sand & Natural aggregate & $\begin{array}{l}\text { Recycled } \\
\text { aggregate }\end{array}$ \\
\hline YUA-01 & \multirow{6}{*}{0.46} & 0 & \multirow{6}{*}{195} & \multirow{6}{*}{423} & 599 & 1162 & 0 \\
\hline A-1 & & 20 & & & 606 & 941 & 235 \\
\hline A-2 & & 40 & & & 606 & 706 & 470 \\
\hline A-3 & & 60 & & & 616 & 478 & 717 \\
\hline A-4 & & 80 & & & 616 & 236 & 959 \\
\hline A-5 & & 100 & & & 623 & 0 & 1209 \\
\hline
\end{tabular}

These conclusions can be drawn According to the results reflected in the above chart:

(1) The strength of concrete specimens with 28-day age is generally higher than that of 7-day concrete specimens. This is due to the strength of concrete is related to the age of the molding. After the concrete is formed, the strength increases with the time, and it begins to grow rapidly, and then gradually becomes slower. It takes 28 days to reach the design value of compressive strength of concrete.

(2) In the $28 \mathrm{~d}$ age of concrete block, the rate of the compressive strength's growth in group A-1 is the largest one, A-4 group is Second, in addition, the group A-1 sets for the 
maximum compressive strength of $36.3 \mathrm{MPa}$. when the dosage of steel slag reach to $60 \%$, the compressive strength of concrete reached minimum, but higher than YUA-01 group, as 31.0MPa, since then, with the increase of steel slag content, compressive strength of concrete has increased slightly.

(3)In the $7 \mathrm{~d}$ age of concrete test block, in addition to the strength of the steel slag admixture of $100 \%$ lower than the group YUA-01, the other groups are higher than the group YUA-01, because the strength of the gravel is greater than the strength of the steel slag recycled aggregate. When concrete is subjected to external force, gravel itself can bearing part stress, weaken some external force, so as to improve the strength of the concrete.

(4) In addition, whether concrete is 28-day age or 7-day age , there is a common point, that is the compressive strength reaches a peak when steel slag recycled aggregate content is $20 \%$. It should be due to that the specimens gravel content is more in group A-1, reducing the number of coarse aggregates' maximum particle size, and macadam's strength is greater than that of the steel slag recycled aggregate, so it is easy to make each aggregate distribution of concrete becomes more uniform in the mixing process, when subjected to external force, internal stress of concrete will be relatively dispersed, so it isn't easy to be damaged

\section{CONCLUSION AND DISCUSSION}

The $7 \mathrm{~d}$ and $28 \mathrm{~d}$ age compressive strength test of different content of steel slag recycled aggregate concrete and natural concrete were carried out to seek the effect of the recycled aggregate replacement ratio on recycled concrete, and further to find out tht optimized steel slag recycled aggregate replacement rate.

The test results proved that it is feasible to replace the natural aggregate with steel slag recycled aggregate. The compressive strength of the recycled concrete is larger than that of the ordinary concrete.

The suitable replacement rate of steel slag recycled aggregate is about $20 \%$ after taking into account the reliability and strength. Replace natural aggregate with recycled aggregate in concrete, can not only realize high added value use of iron tailings with considerable economic benefits instead of simple treated, but also reduce the environment pollution caused by steel plant.

\section{ACKNOWLEDGEMENTS}

This work was financially supported by the science and technology project of Ministry of housing and urban rural development of the people's Republic of China (2015-K4-019), Huaian science and technology project (HAG2014010) and Construction system science and technology project of Jiangsu Province (2014ZD34).

\section{REFERENCES}

[1] Motz, H., and J. Geiseler. "Products of steel slags an opportunity to save natural resources." Waste Management 21.3(2001):285-293.

[2] Yildirim, Irem Zeynep, and M. Prezzi. "Chemical, Mineralogical, and Morphological Properties of Steel Slag." Advances in Civil Engineering2011.1687-8086(2011).
[3] Sorlini, Sabrina, A. Sanzeni, and L. Rondi. "Reuse of steel slag in bituminous paving mixtures." Journal of Hazardous Materials s 209-210.1(2012):84-91.

[4] Mombelli, D., et al. "The efficiency of quartz addition on electric arc furnace (EAF) carbon steel slag stability." Journal of Hazardous Materials 279C(2014):586-596.

[5] Qasrawi, Hisham. "The use of steel slag aggregate to enhance the mechanical properties of recycled aggregate concrete and retain the environment." Construction \& Building Materials 54.11(2014):298-304.

[6] Anastasiou, E., K. G. Filikas, and M. Stefanidou. "Utilization of fine recycled aggregates in concrete with fly ash and steel slag."Construction \& Building Materials 50.50(2014):154-161. 